\title{
The response of saline-sodic soils to reclamation using biological and organic amendments under arid regions of Egypt
}

\author{
Mohamed Hafez ${ }^{1,2, *}$, Alexander I. Popov ${ }^{1}$, and Mohamed Rashad $^{2}$ \\ ${ }^{1}$ Department of Soil Science and Soil Ecology, Institute of Earth Sciences, Saint Petersburg State University, Embankment, 7/9, Saint \\ Petersburg, 199034, Russia \\ ${ }^{2}$ Land and Water Technologies Department, Arid Lands Cultivation Research Institute, City of Scientific Research and Technological \\ Applications, New Borg El-Arab, 21934, Alexandria, Egypt
}

\begin{abstract}
The study focused on investigating the contribution of reclamation strategies of saline-sodic soils and their impacts on soil fertility characteristics. In this study, the soil treatments were denoted as: SG1 and SG2 (23.8 and 47.7 ton/ha of spent grain); TC1 and TC2 (23.8 and 47.6 ton/ha of compost); Azospirillium in inoculation with seed and soil (Az); Az + SG1 (Az+SG1); Az + TC1 (Az+TC1); mineral fertilizers (NPK); and control (CK). All treatments were mixed in pots with $30 \mathrm{~kg}$ soil. The results showed that reclamation with $\mathrm{Az}$ and $\mathrm{SG} 2$ treatments significantly affected soil $\mathrm{pH}, \mathrm{EC}$, and macronutrients. In contrast, no significant $(\mathrm{P}>0.05)$ effects were found with the two compost levels and NPK treatments. The salt contents were maximal in the control treatment, while decreased with Az, SG2, and Az+SG treatments. However, SG2 application decreased the soluble $\mathrm{Na}+$ concentrations in soil solution. The effect of organic and biological reclamations on chemical properties was in the following order: Az+SG $>$ SG2 $>\mathrm{Az}>\mathrm{TC} 2$ $>\mathrm{Az}+\mathrm{M}>\mathrm{SG} 1>\mathrm{TC} 1>\mathrm{NPK}>\mathrm{CK}$. Moreover, it positively impacted the salt contents, which improved soil chemical properties in the saline-sodic soil after three months of seed sowing in the greenhouse.
\end{abstract}

\section{Introduction}

The amelioration and management of salt-affected soils will go a long way to meet the desired $57 \%$ increase in global food production by 2050[1]. The soil salinity can be defined as the dissolved mineral salts accumulated in soil solution and rhizosphere [2]. The atmospheric deposition from sea salts and the intrusion of sea-water into the ground-water of coastal areas are another form of soil salt. Water overuse can significantly decrease the standard water-table [2]. Salt may rise due to soilevaporation and soil-plant evapotranspiration under high water table conditions. Secondary salinity may be caused by irrigation methods and water quality such as brackish water. The salts excess from soil profile may adversely influence biological, physical, and chemical soil properties. In these soils, the exchangeable $\mathrm{Na}+$ is bound to the negatively charged clays, causing the deflocculation of clay particles. As [3, 4] found that the high exch-Na+ percentage can lead to clay swelling and dispersion of clay, as well as soil aggregates breaking. As a consequence, both the water-holding capacity and water infiltration rate could be reduced by this process. As a new way of recycling agricultural wastes to the field, spent grain (SG) directly or indirectly affects soil fertility and ameliorations. SG is the beer industry organic wastes primary product, representing $85 \%$ of the total products generated [5].
Plant growth-promoting rhizobacteria (PGPR) is a bacterium that colonizes herbal rhizospheres and stimulates plant growth using various nitrogen fixation, phosphates availability, quorum sensing, etc. PGPR provides multiple ways of substituting chemical fertilizers, pesticides, etc., thereby increasing demand of bio-fertilizers. It would be fascinating to know the fundamentals and the context behind this remarkable science before continuing with current applications and state of the art PGPR and crop plants. In general, about $2-5 \%$ of the rhizosphere bacteria are PGPR [6]. The objective of the present study was to evaluate the effects of different amendments on reclamation of saline-sodic soil, and their affected-on soil organic and biological ameliorants under greenhouse conditions under arid climate.

\section{Materials and methods}

\subsection{The experimental details and preparation}

Nine treatments were established and shown in Table (2), including two levels of spent grain, SG1 (23.8 ton/ha) and SG2 (47.6 ton/ha); two levels of compost, TC1 (23.8 ton/ha) and TC2 (47.6 ton/ha); injection of Azospirillium with corn seeds and soil (Az); the combination Azospirillum and spent grain (Az+SG1); the combination Azospirillum and compost (Az+TC1);

\footnotetext{
* Corresponding author: mhafez290@yahoo.com
} 
mineral fertilizers (NPK) contained on 75: 15: 25 units of urea, calcium phosphate, and potassium sulfate, respectively. All treatments were mixed with pots $30 \mathrm{~kg}$ soil for 4 months of seed sown and compared to control (CK, without fertilizers). The Azospirillum was cultured and grown and performed at a dose of $1.0 \mathrm{ml}$ per seed.

\subsection{Soil characteristics}

The Egypt region prevailing climate is dry and hot summers and semi-cool and wet winters. The average temperature and precipitation are deficient, $25.6{ }^{\circ} \mathrm{C}$, and $130 \mathrm{~mm}$, respectively. The experimental period lasted from Jun 2017 to Sept 2017. The study site was a calcareous saline-sodic with clay loam texture, with clay concentrations of $\left(453 \pm 0.18 \mathrm{~g} \mathrm{~kg}^{-1}\right.$, silt $235 \pm 0.21 \mathrm{~g} \mathrm{~kg}^{-}$ 1 , and sand $310.2 \pm 0.11 \mathrm{~g} \mathrm{~kg}^{-1}$ ) was determined by the hydrometer as described by [7]. Soil samples were collected from the study site after removing visible roots and fresh litter material; the composite samples were sieved $(<2 \mathrm{~mm})$. The soil chemical properties were determined and shown in Table 1.

Table 1. Saline-sodic soil chemical properties before treatment applications.

\begin{tabular}{|l|c|}
\hline Parameter & Saline-sodic soil \\
\hline $\mathrm{pH}(1: 2.5 \mathrm{w}: \mathrm{v})$ & $8.84 \pm 0.05$ \\
\hline $\mathrm{EC}_{\mathrm{e}}\left(\mathrm{dS} \mathrm{m}^{-1}\right)$ & $5.43 \pm 0.10$ \\
\hline Total N $\left(\mathrm{gkg}^{-1}\right)$ & $0.02 \pm 0.001$ \\
\hline Available $\mathrm{P}\left(\mathrm{mgkg}^{-1}\right)$ & $1.20 \pm 0.07$ \\
\hline Available K $\left(\mathrm{mgkg}^{-1}\right)$ & $78.1 \pm 0.44$ \\
\hline Total CaCO $(\%)$ & $18.6 \pm 1.35$ \\
\hline $\mathrm{CEC}\left(\mathrm{cmol}^{+} \mathrm{kg}^{-1}\right)$ & $7.56 \pm 0.24$ \\
\hline Organic Matter $\left(\mathrm{g} \mathrm{kg}^{-1}\right)$ & $1.78 \pm 0.21$ \\
\hline Soil Organic Carbon $\left(\mathrm{g} \mathrm{kg}^{-1}\right)$ & $1.03 \pm 0.01$ \\
\hline $\mathrm{ESP}^{* *}(\%)$ & $53.1 \pm 1.93$ \\
\hline $\mathrm{C}: \mathrm{N} \mathrm{Ratio}$ & $49.14 \pm 2.1$ \\
\hline \multicolumn{2}{|c|}{ Micronutrients DTPA Extractible $\left(\mathrm{mgkg}^{-1}\right)$} \\
\hline $\mathrm{Fe}^{2+}$ & $0.08 \pm 0.01$ \\
\hline $\mathrm{Zn}^{2+}$ & $\mathrm{Nd}^{*}$ \\
\hline $\mathrm{Mn}^{2+}$ & $0.11 \pm 0.020$ \\
\hline $\mathrm{Cu}^{2+}$ & $0.003 \pm 0.01$ \\
\hline $\mathrm{B}^{+}$ & $\mathrm{Nd}^{*}$ \\
\hline $\mathrm{Cl}^{-}$ & $192 \pm 0.166$ \\
\hline
\end{tabular}

\subsection{Soil analyses}

The soil-plant analysis was performed in cooperation between the soil chemistry and environment laboratory of ALCRI, SRTA-City, Egypt, and laboratory SPbSU University, Russia. The $\mathrm{pH}$ was measured in a soil: water suspension $(1: 2.5 \mathrm{w} / \mathrm{v})$. The electrical conductivity (EC) was measured in saturated paste extracts using an EC meter. Total $\mathrm{N}$ content was determined by the Kjeldahl digestion method. Available $\mathrm{P}$ concentration was extracted with $(0.5 \underline{\mathrm{N}}) \mathrm{NaHCO}_{3}$ and measured using a spectrophotometer at wavelength $880 \mathrm{~nm}$. Available K content was extracted by ( $1 \underline{\mathrm{N}})$ ammonium acetate solution and measured by the flame photometer. The N, $\mathrm{P}$, and $\mathrm{K}$ were measured as explained by [7]. Available $\mathrm{Fe}^{2+}, \mathrm{Zn}^{2+}, \mathrm{Mn}^{2+}, \mathrm{Cu}^{2+}$, and $\mathrm{B}^{+}$concentrations were extracted by DTPA solution and measured with atomic emission spectroscopy as explained by [8]. Soil organic carbon content was determined by oxidization with $\mathrm{K}_{2} \mathrm{Cr}_{2} \mathrm{O}_{7}$. Exchangeable sodium percentage (ESP) of soil was determined using the relationship ESP = $($ Exchangeable-Na $\div \mathrm{CEC}) \times 100 . \quad$ Exch- $\mathrm{Na}^{+}$was extracted with (1 M) ammonium acetate solution. Soil CEC was estimated following the Bower saturation method as outlined by [9].

\subsection{Statistical analyses}

Analysis of variance (ANOVA) and repeated measures/within the subject variance analysis were used to test the effects of depletion (soil carbon and chemical parameters) and soil additives on soil reclamation, germination, plant growth, and yield productivity. Differences were considered statistically significant for $\mathrm{P}$ $<0.05$.

\section{Results and discussion}

\subsection{Effects on macronutrient $\mathrm{Ca}^{2+}, \mathrm{K}^{+}$, and $\mathrm{Mg}^{2+}$}

Data demonstrated that organic and biological treatments influenced the concentrations of macronutrients in saline-sodic soil during the plant growth period (Fig.1). The results revealed that the application of compost, SG and the combination with Azospirillum increased macronutrients concentrations, calcium and magnesium after four months application as follow: $\mathrm{Az}+\mathrm{SG} 1 \geq \mathrm{TC} 2$ $>\mathrm{TC} 1>\mathrm{Az}+\mathrm{TC} 1>\mathrm{Az}>\mathrm{SG} 2>\mathrm{SG} 1>\mathrm{CK}>\mathrm{NPK}$, respectively. The differences in the concentrations of $\mathrm{Ca}^{2+}$ and $\mathrm{Mg}^{2+}$ were significant $(\mathrm{P}>0.05)$ among all treatment applications. The soluble $\mathrm{Ca}^{2+}$ of saline-sodic soil increased by $147.55,147.21,136.25,133.38$, $129.17,114.16,89.88$, and $88.78 \%$ for $\mathrm{Az}+\mathrm{SG} 1$, TC2, TC1, Az+TC1, Az, SG2, SG1, and NPK treatments, respectively in comparison to their $\mathrm{CK}$ treatment. The trend of $\mathrm{Mg}^{2+}$ concentrations was similar to $\mathrm{Ca}^{2+}$ in saline-sodic soil after corn plant harvest. Az+SG1 and TC2 treatments significantly contributed to $\mathrm{Ca}^{2+}$ and $\mathrm{Mg}^{2+}$ were greater than SG1 and $\mathrm{Az}$ treatments at the combination of application rates. This result might be due to that the initial source of TC2 had highly electrical conductivity before soil treatment or dissolving some calcium carbonate by Azospirillum bacteria from the soil. The soluble $\mathrm{Ca}^{2+}, \mathrm{K}^{+}$, and $\mathrm{Mg}^{2+}$ concentrations are shown in (Fig. 1). The results showed that the increases of $\mathrm{Mg}^{2+}$ concentrations behaved similarly to the increases of $\mathrm{Ca}^{2+}$ content among all treatments.

On the other hand, the potassium $\left(\mathrm{K}^{+}\right)$concentration in all treatments was lower than that of $\mathrm{Ca}^{2+}$ and $\mathrm{Mg}^{2+}$. These lower $\mathrm{K}^{+}$values may be due to the low inherent content in the saline-sodic soil or due to slow decomposition rate of organic and bio-organic amendments in soil. Generally, the soluble $\mathrm{K}^{+}$of salinesodic soil increased by $828.57,778.57,596.42,539.28$, 471.42, 467.85,403.57, and $342.85 \%$ for Az+SG1, SG2, SG1, Az, Az+TC1, TC2, NPK, and TC1 treatments, respectively in comparison to their control concentration. 
The SG1+Az and SG treatments positively affected the content of $\mathrm{K}^{+}$significantly $(\mathrm{P}>0.05)$ in the saline-sodic soil. Similarly, $[10,11]$ reported increases in $\mathrm{Ca}^{2+}, \mathrm{K}^{+}$, and $\mathrm{Mg}^{2+}$ concentrations in soil solution of soil treated with organic amendments. In a laboratory experiment on saline-sodic soil reclamation, the effects of deferent organic amendments on the same soluble cations [12] reported significantly $(\mathrm{P}>0.05)$, the soil additives of spent grain and Azospirillum bacteria might provide supplemental soluble macronutrients such as $\mathrm{Ca}^{2+}, \mathrm{Mg}^{2+}$, and $\mathrm{K}^{+}$in leachates of saline-sodic soil.

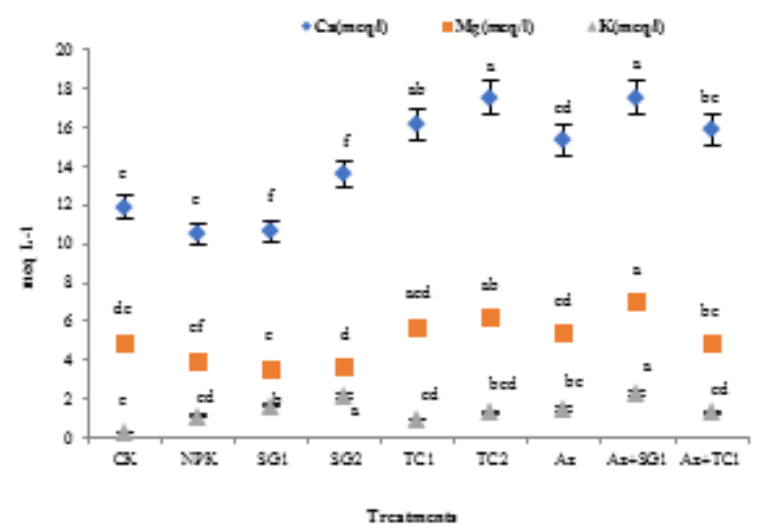

Fig. 1. Influence of organic and biological additives on soil soluble $\mathrm{Ca}^{2+}, \mathrm{Mg}^{2+}$, and $\mathrm{K}^{+}$after three months of corn seed sowing in saline-sodic soil. Data points and error bars represent means, and standard errors $(\mathrm{n}=3)$ were analyzed using a oneway ANOVA. The same letter is not significantly different at the least significant difference $\left(\mathrm{LSD}_{=0.05}\right)$ test $(\mathrm{p} \leq 0.05)$.

\subsubsection{The $\mathrm{pH}$ values after soil application}

Soil $\mathrm{pH}$ is an essential factor that regulates the solubility and availability of plant nutrients. Increasing the availability of plant-nutrients is created by reducing soil $\mathrm{pH}$ in saline-sodic soil. The soil analysis showed that in all treatments, soil $\mathrm{pH}$ was significantly reduced relative to control (Fig. 2). The $\mathrm{pH}$ values of saline-sodic soil treated with organic and bio-organic ameliorants decreased by $2.86,3.22,5.93,6.1,7.54,8.68,8.79$, and $11.53 \%$ for TC1, TC2, Az+TC1, NPK, SG2, Az+SG1, SG1, and Az treatments, respectively compared to CK treatment (Table 3). The soil $\mathrm{pH}$ at $\mathrm{Az}$ treatment alone was decreased, but the effect was reversed in the TC1 and TC2 treatments; no significant $(\mathrm{P}<0.05)$ effect was observed compared with Az and SG1. In the Az and two levels of spent grain treatments, the decrease in soil $\mathrm{pH}$ was enhanced by a combination of $\mathrm{Az}$ and SG1 treatments. The reduction in the $\mathrm{pH}$ values was influenced by the type of amendment and application rate. The increasing application rate of Az and SG1 was enhanced $\mathrm{pH}$ reduction. However, the increase in soil $\mathrm{pH}$ may induce the $\mathrm{Ca}^{2+}$ to become more alkaline and, therefore, more sodic as calcium solubility is suppressed; this was proposed by [12]. In arid and semi-arid climates, the soluble $\mathrm{Ca}^{2+}$ and $\mathrm{Mg}^{2+}$ become low, $\mathrm{Na}^{+}$ and $\mathrm{K}^{+}$ions accumulate in soil solution when $\mathrm{CO}_{3}{ }^{-2}$ and $\mathrm{HCO}_{3}{ }^{-}$increase [13]. [14] found that the applications of organic amendments such as spent grain and
Azospirillum might reduce the soil $\mathrm{pH}$. However, the magnitude of this decrease brought about by $10 \mathrm{t} / \mathrm{ha}$ of spent grain did not reduce the soil $\mathrm{pH}$ sufficiently to influence lime solubility. A long-term soil incubation experiment was conducted to examine different organic amendments on the soil chemical properties with high salinity, which positively impacted soil $\mathrm{pH}$ [15]. On the other hand, [16] found that the organic, bio, and biochar additives did not increase the soil $\mathrm{pH}$ [11] without gypsum which reduced the soil $\mathrm{pH}$.

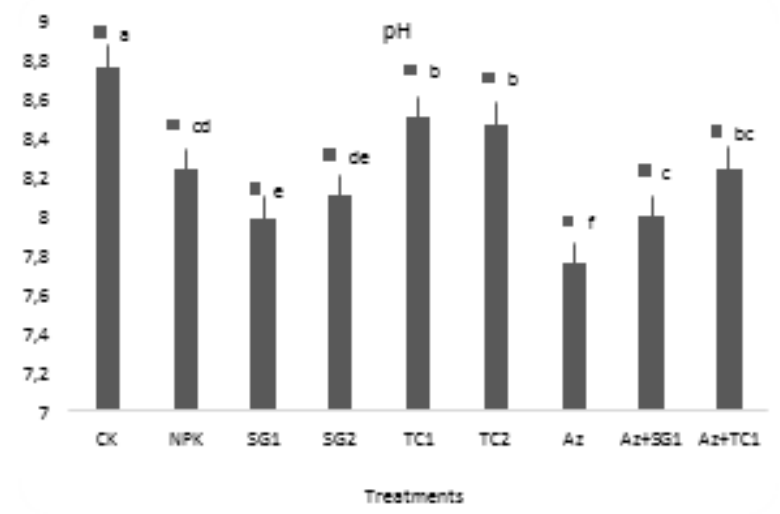

Fig. 2. Influence of organic and biological additives on soil $\mathrm{pH}$ after three months of corn seed sowing in saline-sodic soil. Data points and error bars represent means, and standard errors $(n=3)$ were analyzed using a one-way ANOVA. The same letter is not significantly different at the least significant difference $(\mathrm{LSD}=0.05)$ test $(\mathrm{p} \leq 0.05)$.

\subsubsection{EC concentration after soil treatments}

The high electrical conductivity (EC) of soil affects the crops by reducing water supply (osmotic effects). The EC concentrations in the saline-sodic soil followed the order $\mathrm{TC} 2>\mathrm{NPK}>\mathrm{TC} 1>\mathrm{CK}>\mathrm{Az}+\mathrm{TC} 1>\mathrm{Az}+\mathrm{SG} 1$ $>\mathrm{Az}>\mathrm{SG} 1>\mathrm{SG} 2$, respectively (Fig. 3). The SG2 possessed the lost EC concentrations in saline-sodic soil after four months of soil treatments. The soil EC of SG2, $\mathrm{SG} 1, \mathrm{Az}, \mathrm{Az}+\mathrm{SG} 1$, and $\mathrm{Az}+\mathrm{TC} 1$ treatments were significantly $(\mathrm{P}<0.05)$ different compared to the control. Simultaneously, the EC concentrations of TC2, NPK, and TC1 did not differ significantly from control. These reactions help infiltration, flocculation, and stability of water. The EC concentrations were increased by the additions of NPK, TC1, and TC2 treatments because the initial EC for these treatments was high. When $\mathrm{Az}+\mathrm{TC} 1$ was applied to the soil, the EC decreased more than that EC with $\mathrm{TC} 1$ treatment. Our funding agreement with [11] found the applications of biochar or organic amendments have decreased the $\mathrm{Na}^{+}$soil salinity as much more than the conventional amendment of gypsum. These indicate that the compost application at ( 23.8 and/or 47.6 ton/ha) may be too much to affect salts solubility in saline-sodic soils. The low EC concentrations in the treated soil with SG2 and Az are due to this reduction in the salt concentration by spent grain and Azospirillum bacteria. The low osmotic effects in the soil treated with SG2 and Az could result from the sodium complex with organic matter as a sodium humate 
form. These results were agreed with [12]. Also agree with $[11,13]$ found the exchange complexes forming $\mathrm{Ca}^{2+}$ by exchanging with $\mathrm{Na}^{+}$from the cation exchange complex $\mathrm{Na}_{2} \mathrm{SO}_{4}, \mathrm{MgSO}_{4}$, and other high-solubility salts illustrate this decrease in EC concentrations.

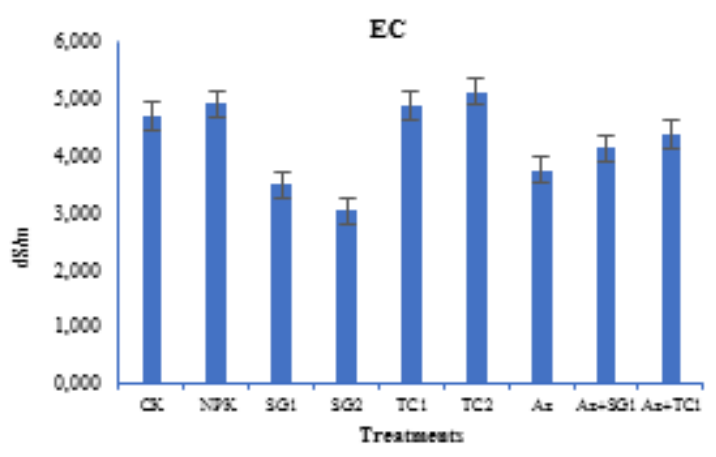

Fig. 3. Influence of organic and biological additives on soil EC after three months of corn seed sowing in saline-sodic soil. Data points and error bars represent means, and standard errors $(\mathrm{n}=3)$ were analyzed using a one-way ANOVA. The same letter is not significantly different at the least significant difference $\left(\mathrm{LSD}_{=0.05}\right)$ test $(\mathrm{p} \leq 0.05)$.

\subsection{Effects on soil fertility}

\subsubsection{Organic matter content}

The increases in soil organic matter (OM) and organic carbon (SOC) content were observed in all treatments, except Az, CK, and NPK, due to the low input of organic material by these treatments (Fig. 4). Also, OM content increased significantly $(\mathrm{P}<0.05)$ for SG2, TC2, $\mathrm{Az}+\mathrm{SG} 1$ treatments were 1.94, 0.946, $0.754 \%$, this increase was by $1388.37,1100$ and $876.7 \%$, respectively after three months of seed sowing. The lowest OM contents were with $\mathrm{Az}, \mathrm{NPK}$, and CK treatments were $0.160,0.096$, and $0.086 \%$. On the other hand, the SOC content trend was the same with the trend of OM content in the saline-sodic soil followed the order: SG2 $>$ TC2 $>$ $\mathrm{SG} 2>\mathrm{Az}+\mathrm{SG} 1>\mathrm{SG} 1 \geq \mathrm{Az}+\mathrm{TC} 1>\mathrm{Az}>\mathrm{NPK} \geq \mathrm{CK}$. No significant differences were observed between treatments SG1 and Az+TC1 and NPK and CK treatments. These enhancements of the OM and SOC contents in the saline-sodic soil with SG2, TC2, and $\mathrm{Az}+\mathrm{SG} 1$ treatments due to higher organic matter content for raw materials of spent grain and compost were added to the soil. SOC content increased after organic matter additives to soil and organic matter decomposition by microorganisms. The findings in (Fig. 3) further showed that the combination of Azospirilum with both sources of organic additives significantly improved soil OM and SOC contents over control and NPK and Az only. However, there was still a great effect of growing corn under saline-sodic soil with these treatments. The results agree with other researchers that found the organic amendments such as spent grain and compost significantly increased the soil organic matter and organic carbon contents in soil [17] also, reported the combination of organic sources with $50 \%$ of NPK fertilizer enhanced OM content after crop harvest.

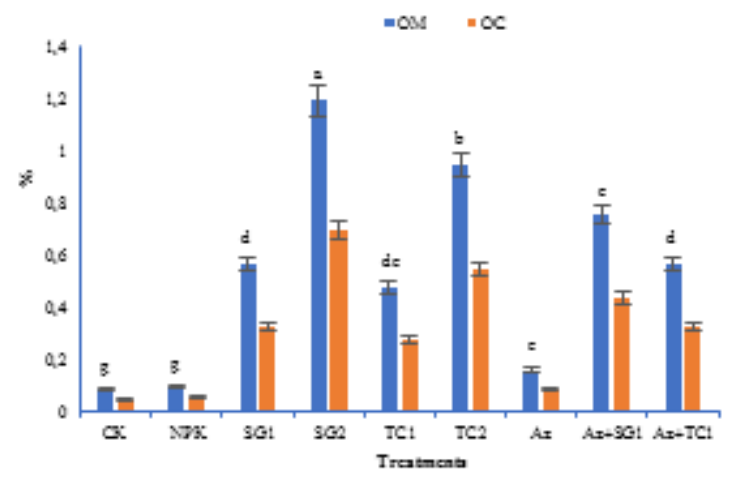

Fig. 4. Influence of organic and biological additives on soil $\mathrm{OM}$ and $\mathrm{OC}$ after three months of corn seed sowing in salinesodic soil. Data points and error bars represent means, and standard errors $(\mathrm{n}=3)$ were analyzed using a one-way ANOVA. The same letter is not significantly different at the least significant difference $\left(\mathrm{LSD}_{=0.05}\right)$ test $(\mathrm{p} \leq 0.05)$.

\section{Conclusion}

The organic amendments to soil showed higher $\mathrm{Ca}^{2+}$, $\mathrm{Mg}$, and $\mathrm{K}$ concentrations; however, this was depending on the OM decomposition rate of organic additives. The injection of Azospirillum bacteria with corn seed and saline-sodic soil improved $\mathrm{pH}, \mathrm{EC}$, and plant growth. Therefore, SG2 and Az applications are found to be ideal for saline-sodic soil amelioration and are an effective way to increase nutrients availability and corn plant productivity under greenhouse in arid regions.

We thank the Colleagues Department of Soil Science and Soil Ecology, Institute of Earth Sciences of St. Petersburg State University, Saint Petersburg, Russia, Colleagues Department of Land and Water Technologies, Arid Lands Cultivation Research Institute, City of Scientific Research and Technological Applications, Alexandria, Egypt, and Cultural Affairs and Missions Sector, Ministry of Higher Education and Scientific Research.

\section{References}

1. S. Arora, A.K. Singh, Y.P. Singh, Bioremediation of Salt Affected Soils: An Indian Perspective, Bioremediation of Salt Affected Soils: An Indian Perspective (Cham: Springer International Publishing, 2017, 1-313)

2. M. Diacono, F. Montemurro, Effectiveness of Organic Wastes as Fertilizers and Amendments in Salt-Affected Soils, Agriculture, 5 (2), 221230 (2015)

3. Y. Zhao, et all, Extensive reclamation of salinesodic soils with flue gas desulfurization gypsum on the Songnen Plain, Northeast China, Geoderma, Elsevier, 321 (1), 52-60 (2018)

4. R. Erel, et all, Long-term irrigation with reclaimed wastewater: Implications on nutrient management, soil chemistry and olive (Olea 
europaea L.) performance, Agric. Water Manag. Elsevier, 213, 324-335 (2019)

5. S.I. Mussatto, I.C. Roberto, Chemical characterization and liberation of pentose sugars from brewer's spent grain, J. Chem. Technol. Biotechnol., 81 (3), 268-274 (2006)

6. A.M. Negm, M. Abu-hashim, Sustainability of Agricultural Environment in Egypt: Part II, The Handbook of Environmental Chemistry, Cham: Springer International Publishing, 77, 317-347 (2019)

7. J.P.E. Anderson, A.L. Page, R.H. Miller, D.R. Keeney, Methods of Soil Analysis and Soil Respiration (1982)

8. P.N. Soltanpour, A.P. Schwab, A new soil test for simultaneous extraction of macro- and micronutrients in alkaline soils, Commun. Soil Sci. Plant Anal., 8 (3), 195-207 (1977)

9. L.A. Richards, Diagnosis and improvement of saline and alkali soils, Soil Sc, 78-154 (1954)

10. M. Mahmoodabadi, et all, Reclamation of calcareous saline sodic soil with different amendments (I): Redistribution of soluble cations within the soil profile, Agric. Water Manag. Elsevier B.V., 120 (1), 30-38 (2013)

11. V.N. Chaganti, D.M. Crohn, J. Šimůnek, Leaching and reclamation of a biochar and compost amended saline-sodic soil with moderate SAR reclaimed water, Agric. Water Manag. Elsevier B.V., 158, 255-265 (2015)

12. M. Hafez, A.I. Popov, M. Rashad, Evaluation of the Effects of New Environmental Additives Compared to Mineral Fertilizers on the Leaching Characteristics of Some Anions and Cations under Greenhouse Plant Growth of Saline-Sodic Soils, Open Agric. J., 14 (1), 246-256 (2020)

13. T. Zhang, et all, Effects of different amendments for the reclamation of coastal saline soil on soil nutrient dynamics and electrical conductivity responses, Agric. Water Manag. Elsevier B.V., 159, 115-122 (2015)

14. M. Hafez, A.I. Popov, M. Rashad, A Novel Environmental Additives to Decrease Nitrate Level in Agriculture Wastewater and Enhancement Nutrient Status under Greenhouse Plant Growth in Calcareous Soil, Plant Arch., 20, 3165-3172 (2020)

15. Y. Yu, et all, Effect of organic materials on the chemical properties of saline soil in the Yellow River Delta of China, Front. Earth Sci., 9 (2), 259-267 (2015)

16. Y. Shi, X. Liu, Q. Zhang, Effects of combined biochar and organic fertilizer on nitrous oxide fluxes and the related nitrifier and denitrifier communities in a saline-alkali soil, Sci. Total Environ., 686, 199-211(2019)

17. M.A.E. Hamdia, M.A.K. Shaddad, M.M. Doaa, Mechanisms of salt tolerance and interactive effects of Azospirillum brasilense inoculation on maize cultivars grown under salt stress conditions, Plant Growth Regulation, 44 (2), 165-174 (2004). 